\title{
Cultural Identities of the Well-Educated Chinese Immigrant Children in the UK
}

\author{
LUAN Ming-xiang \\ University of Chinese Academy of Social Sciences, Beijing, China
}

\begin{abstract}
Since the Reform and Opening-up in 1978, China has broadened and deepened its exchanges and relations with other countries. This has contributed to the increase in the migration of well-educated Chinese abroad and United Kingdom (UK) has become a most desirable destination for the elite Chinese immigrants. The impact of the migration of well-educated Chinese deserves particular attention and study, especially the second generation's cultural identities - this under-researched topic is the focus of this study. The study investigates the cultural identity differences between Chinese born children (CBC) and British born children (BBC) of the Chinese intellectual families living in Britain. Results indicated that both CBC and BBC had high pride in Chinese and British culture. No significant evidence for cultural identity crises was found. The children investigated considered themselves as bi-culturalism and were content with “dual identities,” with the CBC a bit more Chinese, while the BBC a bit more British. Much smaller differences in views of cultural identity were reported.
\end{abstract}

Keywords: Culture, Cultural clash, Cultural identity, Chinese born children (CBC), British born children (BBC)

\section{Introduction}

In the era of globalization, people from different cultures live, work, or study together. The general trend is that people from developing countries migrate to developed countries. Consequently, many immigrant children have the feeling that their parents have difficulty in understanding them. They feel as if their parents were from a different world. Chinese intellectual immigrant children in the United Kingdom (UK) are no exception. For those who were raised in British culture but whose parents were raised in Chinese culture, the cross-cultural dilemma is a daily reality. For those Chinese children who live and study in Britain, cultural clashes are inevitable and they are not easy to be tackled with. They have to face a struggle to maintain their Chinese heritage while living in a completely different British culture.

Recent decades have witnessed increased awareness about the issues of cultural clashes and cultural identities. Numerous cultural and social studies have investigated the issues of cultural differences and cultural identities. Hofstede, a pioneer in the field of cross-culture studies, undertakes one of the most comprehensive surveys. His famous cultural dimension theory develops a model of cultural differences and is the foundation for later researchers. Huntington's (1993) "The Clash of Civilizations and the Remaking of World Order" has obtained its centrality in the contemporary academia, while Hall's (1996) "Questions of Cultural Identity" lies at the heart of current debates in cultural studies and social theory.

LUAN Ming-xiang, M.A., associate professor, Foreign Language Department, University of Chinese Academy of Social Sciences. (This paper is sponsored by China Youth University for Political Sciences.) 
In Hofstede's (2001) view, cultures are different from one society to another. Some are even at bi-polar scales, such as Chinese and British cultures. Peoples from different cultures mix together, clashes or even conflicts are inevitable to arise. Cultural clashes tend to generate culture shock. People all experience culture shock to some degree while living, studying, and working overseas. This is a quite normal and predictable phenomenon and is not a sign of weakness. However, responses to culture shock are in great diversity. No matter what kind of attitude or attitudes people take, they all face the issue of cultural identity confusion or cultural identity loss to some extent, especially when one civilization attempts to impose its values on people of a different civilization.

People in Britain and China have a belief that a child's sense of cultural values have been set at the age of 5 or 6 years. Researchers have also indicated that between the ages of 3 and 9 years (Helms, 1994; Saenz et al. 1995, as cited in Sawrikar \& Hunt, 2005), children are able to use appropriate ethnic labels like skin colors, facial features, and/or language to identify themselves. They understand that they will always belong to that group and make social comparisons regarding the value of one group over another. Psychologist Ghuman (1999) himself argued that children become aware of their own racial origin as early as the age of 5 years old. Hofstede (2005) views culture as an onion. The core, or the basic assumptions, which are in the center of one's beliefs, are not changing once set. Everyone has a stable core of self. Adolescents are in a critical period for the development of cultural identity for they come to understand themselves and their relations with others (Sawrikar \& Hunt, 2005). It is asserted that adolescents who identify themselves with both cultures would reap the greater rewards as they would benefit from the ability to function across, and interact with, several cultural groups. They are more able to resolve differences in cultural value differences between their native and host cultures (Parker, 1995).

In Britain, Chinese second generation face two important challenges: establishing a set of cultural values and developing a cultural identity under the diverse cultural differences of the society. These challenges are resolved by balancing a root and host orientation. It is hypothesized that Chinese born children (CBC) may have more cultural clashes and cultural identity conflicts than British born children (BBC).

This study aims at finding out cultural identity differences between $\mathrm{CBC}$ and $\mathrm{BBC}$ in the of the Chinese immigrant second-generation residing in the UK. The seriousness of children's cultural clashes will be examined to see whether they are related to and affect children's cultural identity formation. Meanwhile, it tries to explore the functions of family in the formation of children's cultural identities so as to further expose the relationships between cultural clashes and cultural identities in the expectation of obtaining a better understanding of the cultural identities among Chinese immigrants' second-generation in the UK. Its long-term goal is to help Chinese immigrants, especially young generations, to become culturally competent in the adaptation to British culture.

\section{Culture and Cultural Identity}

\section{Culture}

Culture means "the way of life of a group of people" (Kidd, 2002). Culture is learned and it is not genetic. It is something acquired because where one is raised (Hall, 1990). Cultural clashes occur when two or more cultures disagree about their beliefs or ways of life.

Hofstede (2005) depicted culture as an onion with four layers in it. From the outermost layer to the innermost are symbols, heroes, rituals, and values. See Figure 1. 


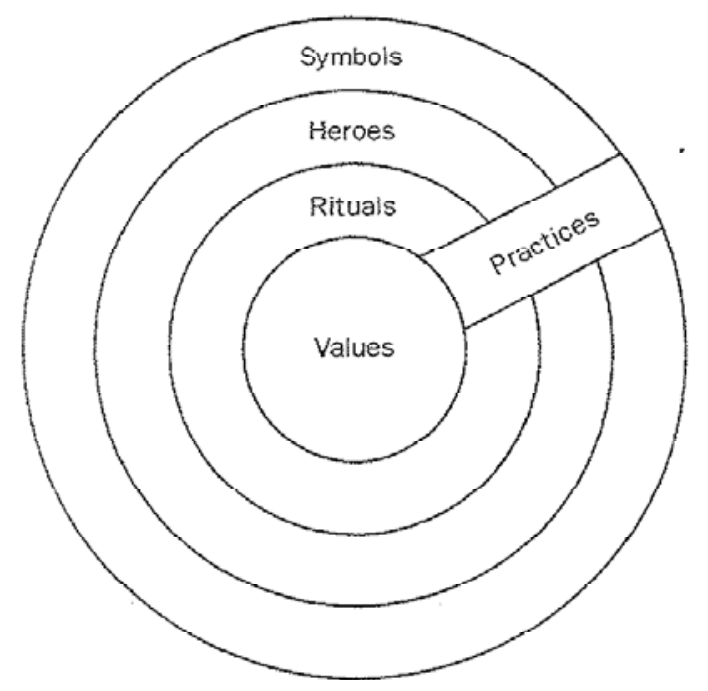

Figure 1. Manifestations of the layers of culture. (Hofstede, 2005, p. 7)

The innermost layer, the core of culture, is formed by values. Values are ideas about what in life is important. They guide the rest of the culture. Values are acquired early in our lives, because at that time a person is most susceptible to learning and assimilating (Hofstede, 2005, p. 2). The learning pattern has been shown in the following.

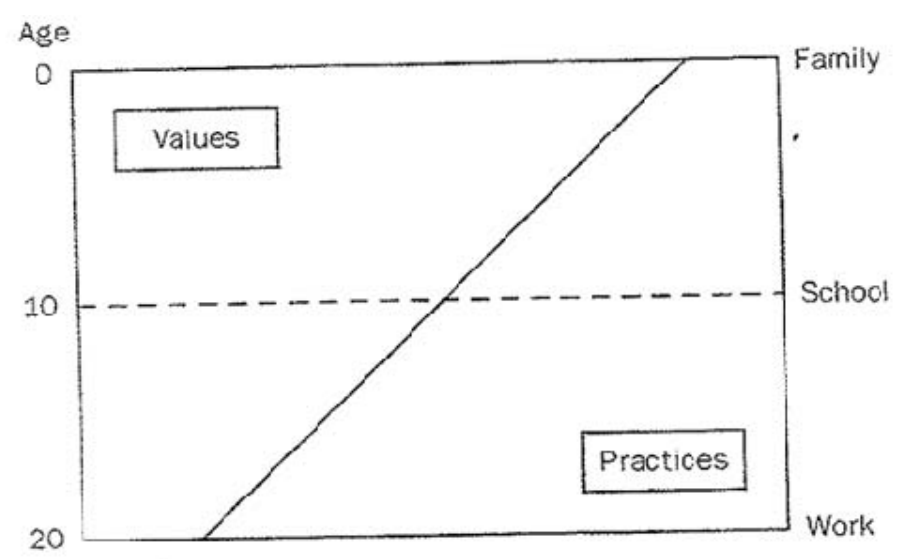

Figure 2. The learning of values and practices (Hofstede, 2005, p. 9)

Figure 2 shows that the acquisition of values is finished at about the age of pre-schooling, which means family plays the most dominant role. This evidence coincides with my hypothesis that a child's cultural values are set at about the age of 6 years. It also coincides with the British belief that a child's cultural values are set at about the age of 5 years.

Culture is different from society to society. Cultural differences are represented in several ways. For instance, the languages in the two cultures are different (English and Chinese), so are their religious beliefs, customs, traditions, heroes, values, and so on. British culture is generally classified as individualism. In Britain, people's individual interests are dominant. Individuals tend to look after themselves and their immediate 
families. They emphasize freedom and ties among them are loose. In contrast, China is regarded as a collective society. People in China usually have close ties. They belong to in-groups (extended families, villages, tribes, etc.) and are supposed to look after the interests of the group, while the group provides protections for individuals in exchange for loyalty (Hofstede, 2005; Trompanaars \& Hampden-Turner, 1997). In China, people give precedence to the interests of groups, especially families, over the individual needs of members. Chinese people traditionally consider the needs of their whole family over their individual preferences. Harmony is valued with confrontation avoided. "Filial piety" is a concept that builds and maintains unity and order in Chinese families (Lewis, 1995; Hofstede, 2005). Family structure is traditionally hierarchical and patriarchal. The family is the foundation of society, regarded as the crucial arena for the reproduction of Chinese norms and values and the key site for the development of cultural identity (Parker, 1995, p. 51).

\section{Cultural Identity}

Cultural identity means a sense of feeling of belonging to a distinct ethnic, cultural, or sub-cultural group. In other words, it means that an individual identifies himself/herself as being similar to or having something in common with the other members of the group. Cultural identity addresses the issues of place, gender, race, history, nationality, sexual orientation, religious beliefs, and ethnicity (Kidd, 2002).

Cultural identity is a field of study that looks at the relationships between individuals and society. Its aim is to understand how people from different cultures mix together harmoniously so as to produce some guidelines with which people from different cultures can better communicate with each other (Kidd, 2002).

The concept of identity, the relationships between individuals and society, is so important to society that without it social life is unimaginable. For it seems that we cannot do without some concepts with which to think about cultural identity, with which to query and confirm who we are and who others are. Without cultural identity, there is no society (Jenkins, 1996).

An individual's sense of identity is achieved by personal choices regarding who and what to associate with. Cultural identity is revealed through the use of markers, such as language, dress, behavior, and choice of space, whose effect depends on their recognition by other social beings. Markers help to create the boundaries that define similarities or differences between the marker revealers and the marker perceivers. Their effectiveness depends on a shared understanding of their meaning. In a social context, misunderstandings can arise due to a misinterpretation of the significance of specific markers, which may result in cultural clashes (Kidd, 2002).

There is evidence that language is not only universally regarded as the core element of one's culture, for it encapsulates people's "world views" and is the chief instrument for the transmission to posterity of values, attitudes, sentiments, and skills (Kidd, 2002), but also a cultural identity marker. It plays an important part in one's identity construction. For example, to the Chinese, the teaching and learning of their mother tongue is considered imperative for passing on familial values of filial piety and respect for elders, as the Chinese characters are regarded as an intrinsic part of the Chinese culture. It is important in the maintenance of distinctive cultural identity. Chinese parents in Britain have expressed their deep concern over their second generation's Chinese language capability, for their children, especially the BBC, cannot hold a conversation solely in Chinese in some cases (Ghuman, 1999).

Researches have shown that the greater the cultural clashes, the more native cultural identity the children will have, and vice versa. In terms of $\mathrm{CBC}$ and $\mathrm{BBC}$, $\mathrm{BBC}$ should have more British cultural identity compared with that of $\mathrm{CBC}$, for $\mathrm{CBC}$ should have greater cultural clashes compared with BBC. On the other hand, 
children's relationships with their parents will also influence their cultural identities. The closer their relationship with their parents, the more Chinese cultural identity they may retain, and vice versa. Children's relationship with his/her teachers, classmates, and/or schoolmates is another influential factor. Better relationships tend to generate the children's preference to his/her school, so that he or she may adapt themselves to the host culture more.

\section{Method}

As an empirical qualitative research, semi-structured interviews as well as structured interviews are adopted. Semi-structured interviews (in-depth, one-to-one interviews) are conducted with both the children and their parents to collect information needed in order to understand their point of views on cultural clashes and cultural identities. Open-ended questions are applied in the survey. However, semi-structured interview is time consuming and structured-interviews that is based on questionnaires helps to acquire background information. Therefore, structured interviews, together with one-to-one interviews, are also adopted. These types of interviews are best suited for engaging in focused group studies, in which it would be beneficial to compare/contrast participant responses in order to answer a research question (Lindlof \& Taylor, 2002). For structured qualitative interviews, it is usually necessary for researchers to develop an interview schedule to increase the reliability and credibility of research data (Lindlof \& Taylor, 2002).

The research is conducted in Britain, one of the most multi-cultural countries with an increasing rise of Chinese intellectual group in the passing decades. Since a child's cultural identity is formed at a very early age, usually at 5 or 6 years old, and mostly at home, this study thus focuses on the families as the research background. Six Chinese immigrant families from mainland China are sampled. The parents are well-educated intellectuals and they are both professionals. They migrated to the UK during the late 80s or 90s last century. The cases studied should have two children in one family (BBC and CBC): It is better that one child was born in China and brought to Britain after the age of 5 or 6 years, but not older than 10 years old and the other child was born in Britain and is now in his/her teens. The reason is that if children's age differs greatly in a group, the findings may lack reliability and validity.

Accordingly, the subjects are two groups of children: group A (CBC) was born in China and came to Britain after 6 years old and now aged 20; group B (BBC) was born in the UK, now aged in their teens. All Participants receive their education in the UK. Their parents all have had a higher level of education, mostly with Master's degree, some with doctor's degree. They are all professionals and belong to middle or upper middle class (with single adult income over 13,400 pounds per annum).

As is said earlier, the purpose of this study is to explore which factor plays the most important role in the confrontation of cultural clashes: family or school. Therefore, two different set of questionnaires were designed in order to get comparatively more complete data: one for parents and the other for their children. The questions can be divided into three categories: questions related to family life, questions related to school education, and questions related to social activities.

In-depth, semi-structured interviews have been launched ever since 2008, but concentrated interviews were conducted between May and late June 2009. The interviews were taken at the participants' homes and lasted about one hour. The participants did the questionnaires first, followed by discussions on some open-ended questions to elicit more detailed answers. The atmosphere was quite friendly owing to the intimate relationships between the interviewer and interviewees. 


\section{Findings and Discussions}

These immigrant children claimed that they experienced little cultural identity issues during their adaptation to the British culture. On the contrary, they said they had more advantages because they digested the best of both cultures. This finding is in opposition to Huntington's theory and other researchers' findings (Huntington, 1993; Parker, 1995; Ghuman, 1999).

\section{The Children Have Dual Identities}

The children as well as their parents all claimed that they had 'dual identities'. This result coincides with the findings of other researchers (Ghuman, 1999; Werbner \& Modood, 1997). Since there are no serious cultural clashes reported, the children are freed from cultural identity dilemma or crises. They are all fully aware who they are and who they want themselves to be. This proves the hypothesis that cultural identities are positively correlated to cultural clashes. That is the more cultural clashes children encounter, the more confused they will be in cultural identity construction (Parker, 1995). The fewer cultural clashes they experience, the more confident they will have in deciding who they are and who they want themselves to be. For example, to the question, "Who do you think you are: British or Chinese?" the children all replied "both," which is also relevant to Modood, et al.’s (1997) findings: "Chinese are among the lowest rate in identifying themselves as British.”

The parents' view about their children's cultural identities was a bit different from that of the children. They reported that cultural identity confusion did occur in the children's early years. They were in a dilemma of deciding who they were: British or Chinese. But as they grew older, they were more and more at ease. For example, Zhang's parents said that their children got confused or lost when they were small. They assumed they were British because they were legalized British citizens and were educated in British schools. But this confusion lasted only for one year or so. As they grow older they increasingly assume that they are Chinese no matter where they live. They think they can never be totally British even though they try their best to integrate themselves into the British way of life.

\section{There Are Cultural Identity Differences Between CBC and BBC, But Not as Significant as Hypothesized}

Cultural identity differences are found between the two groups of children. Generally speaking, all the eight children are in-between generation in cultural identity. However, $\mathrm{CBC}$ are more Chinese with the exception of Liu's older daughter who considers herself to be more British, while BBC are more British except Liu's younger daughter who says that she is more Chinese. Other examples also show that there are cultural identity differences between $\mathrm{CBC}$ and $\mathrm{BBC}$. The $\mathrm{CBC}$ is more fluent in speaking Chinese and they use Chinese language more often than the BBC. They like watching Chinese programs, show more concern with the Chinese current affairs, and are more willing to observe their parents precepts compared with the BBC. However, the difference is not quite significant, just a bit in degree, and it may not solely be the result of culture and/ or age but also the family.

\section{Family Plays an Essential Part in Reducing Their Children's Cultural Clashes and in Children's Identity Formation}

One of the important findings is that family influence is the most essential factor in children's cultural identity formation. Parents' attitudes towards British and Chinese cultures greatly affect their children's cultural identities, and their educational level is extremely important in helping their children overcome cultural clashes 
and provide them with a healthy environment for development. For example, all the parents interviewed have positive attitudes to both Chinese and British cultures. They consider China as a great country and are proud of being Chinese. At the same time, they also express their preference to British culture, and otherwise, they would not choose to stay in the UK. They appreciate British culture as it values independence, creativity, freedom, equality, and so on. Children follow in their parents' footsteps as far as cultural values are concerned. Under such family influences, both $\mathrm{CBC}$ and BBC interviewed also have positive attitudes to both Chinese and British cultures, and they are content with having dual identities.

Families play a critical role in shaping their children's cultural identities. The typical example is Liu's family. In Liu's family, the older daughter is more British in identity than that of her younger sister. The older daughter cannot speak Chinese well. She does not like watching Chinese programs or celebrating Chinese festivals but likes going to pubs. She does not care about what happens in China, nor does she has the intention of visiting China. The younger daughter, however, is more Chinese in identity. She likes watching Chinese programs, but hates pubs. She speaks Chinese at home and reads Chinese stories. She respects and obeys her parents, especially her grandmother's precepts even though she does not agree with them. She considers everything Chinese as good except the dirty toilets.

The reason for the unexpected results is that the older daughter was brought to Britain at 4 years old, a bit earlier for establishing her Chinese cultural values. When she was small, her parents were busy and spent less time with her, so she had more freedom and opportunities to mix with her British teachers and schoolmates. In contrast, the younger daughter, though born in the UK, has been cared by her grandmother, a very traditional Chinese old lady. She has been exposed to Chinese culture more than British culture. Consequently, she is more Chinese while her older sister is more British. This once again proves that a child's cultural values are established around the age of 5 or 6 years. It also proves that family is really important in children's cultural identity formation.

Next to family, school education also affects the development of young people's cultural identity. In Britain, schooling is compulsory up to the age of 16 years and prepares them for their future roles. The children interviewed all like their schools and are academically successful, which enhances the children's preference to British culture so that they are willing to adopt British identity. In addition, the new trend of bilingual education in Britain further strengthens Chinese immigrant children's links with Chinese culture. As all these children choose Chinese as their second language, they have more opportunity to learn Chinese culture. As a result, they know much better about Chinese culture and are proud of being Chinese.

\section{Language is an Important Marker in Judging the Children's Cultural Identities}

These families are mostly bilingual, with the BBC increasingly using English as their first language.

It is important to note that all the children show a decline in their ability to use their mother tongue, especially in writing, even though the parents constantly emphasize the importance of learning Chinese language. As mentioned earlier, language is an important marker for one's cultural identity. The children, especially BBC tend to converse mainly in English, especially when conversing with their siblings and friends. They prefer listening to English pop music, watch English programs, and read English books. The influence of the British culture on the children tends to be greater than that of traditional Chinese culture. 


\section{Conclusion and Suggestion}

\section{Dual or Multiple Cultural Identities can be Advantageous to the Second Generation of Chinese Immigrant Children}

The present study suggests that children with dual identities may be more competitive in their future life. The children interviewed, together with their parents, all express their appreciation of bicultural identities. They see the exposure to two cultures as an opportunity to enrich their lives and increase their competitiveness. For example, the older daughter from Liu's family said that "having the advantage of understanding both sides (which means both cultures) is extremely advantageous." Studies have also shown that bicultural adolescents may be better adjusted, more flexible, and better able to mediate acculturative stress in culturally ambiguous circumstances. It is a more humane and functional strategy (Domanico et al. 1994; Berry, 1997; cited in Ghuman, 1999).

\section{Cultural Clashes and Cultural Identity Confusion can be Avoided or Even Eradicated by Developing not Only Cross-Cultural Knowledge and Awareness but Also Cross-Cultural Competence and Commitment}

There are fundamental differences between some of the values and social conventions of the British schools and of the Chinese immigrant families. The Chinese immigrant children are sure to confront identity crises. To cope with the differing expectations of home and school, the children have adopted the strategy of integration: preserving core elements of Chinese culture, while at the same time combining and synthesizing it with key elements of British culture.

To avoid cultural clashes, the task is to teach children the knowledge about both cultures, and how to operate within them effectively without requiring changes in children's identity and loyalty and to develop positive feelings about both cultures. Once they are aware of and are armed with the knowledge of both Chinese and British cultures, they will develop intercultural competence to handle difficulties they encounter.

To summarize, the overall findings from the research have demonstrated that the children are happy with dual identities and that cultural identity differences exist between BBC and CBC, even though they are not significant. Generally speaking, BBC is more in tune with the British way of life compared with CBC. Meanwhile, they do not reject their root culture. They are keen to retain the key elements of their parents' culture. In addition, China's economic revitalization and political reform make them proud of being Chinese.

Therefore, the children are culturally competent. Family and parents' cultural awareness has helped these children to overcome cultural clashes and further helped them to reduce identity crises.

\section{Conclusion}

Theoretically and practically, there are clashes or overlaps between British and Chinese cultures. However, these immigrant children experience very few cultural clashes and they know very well who they are and who they want themselves to be, which are consistent with my hypotheses of the study. That is, cultural clashes are positively related to cultural identities: the fewer cultural clashes a child encounters, the less confused he or she will be in cultural identity. The CBC's cultural identities are a bit different from the BBC's, which gives further evidence to Hofstede's theory and my hypothesis that a child's cultural values are established at about 5 or 6 years old. It is important to point out that the findings are not consistent with other studies which show that cultural identity crises exist among Chinese immigrants in the UK under the circumstances of greater cultural differences. (Parker, 1995; Ghuman, 1999) 
The study shows that total assimilation of other minority ethnics is not possible. The best way is to show respect to all cultures. Mutual respect is the best solution to diminish cultural clashes to benefit both the Chinese immigrants and the British society. And it is the host society's responsibility to change their attitudes to embrace multiculturalism in the age of globalization. For instance, immigration usually happens to people from underdeveloped cultures to developed countries like Chinese immigrants to Britain. People from developed societies tend to have the view that their culture/cultures are superior to those of the immigrants. Such attitude can make the immigrants feel inferior and thus may lead to cultural conflicts. The immigrants, together with their children, if feeling biased, may be hostile to the host culture and they may have to struggle over their cultural identities. It is important to note that the British government, as well as many other organizations, have realized this phenomenon and endeavored to promote multiculturalism. This is very effective but more efforts should be made in order for all people to have the sense of equality between cultures.

The theme of this study remains on Chinese immigrant children's cultural identity. This research is carried out with a view of drawing as detailed a picture as possible of the day-to-day realities of their concerns and preoccupations. It indicates that traditional cultural identity remains strong among the Chinese immigrant families in the UK. Parents or families are the most essential factor in building children's identities. The children favor biculturalism and bilingualism and prefer integration to other modes of adaptation (e.g. assimilation, marginalization and separation). Although parents are of interest in their own right, their primary function is to help illuminate children's experiences and identities. It is the intention of this study to make research-based information available to a wide audience so that it may lead to a better understanding of the issues raised here. It is hoped that in time it will contribute to positive outcomes for all Chinese children in the UK.

This study provides a detailed description of well-educated Chinese immigrants' second generation's cultural identities. The findings reflect the views and perceptions of a small number of Chinese immigrants in Britain. The usual weaknesses of small scale qualitative research are to be found in this work but nevertheless it adds another piece to the understanding of cultural clashes and cultural identity of Chinese intellectuals' second generation. Hence, the conclusions may not be representative but indicative and we need to be careful when interpreting and generalizing the results to other Chinese immigrant groups. More research should be carried out in order to explore these issues in greater depth and to raise the immigrants' awareness about their young children's cultural identity issues and find better solutions to these problems.

\section{Bibliography}

Anderson, J. (2001). Assignment and thesis writing. New Jersey: John Wiley and Sons Inc.

Archer, L., \& Francis, B. (2007). Understanding minority ethnic achievement: Race, gender, class and success. London: Routledge.

Berg, R. B. (2000). Qualitative research methods for social sciences. Boston: Allyn \& Bacon.

Bhatti, G. (1999). Asian children at home and at school. London: Routledge.

Cable, V. (1994). The world's new fissures: Identities in crisis. London: Demos. ISBN: 1898309353

Dittmer, L., \& Kim, S. S. (Ed.). (1993). China's quest for national identity. Ithaca, NY: Cornell University Press.

Du gay, P., Evens, J., \& Redman, P. (2000). Identity: A reader. London: Sage Publication Ltd.

Fox, K. (2005). Watching the English: The hidden rules of English behavior. London: Hodder \& Stoughton.

Fraser, R. (2004). A people's history of Britain. London: Chatto \& Windus.

Garvey, A., \& Jackson, B. (1975). Chinese children. research and action project into the needs of Chinese children. Cambridge: National Education Research Development Trust. 
Ghuman, P. A. S. (1999). Asian adolescents in the west. London, UK: BPS Books. ISBN: 1854332848

Hall, S., \& du Gay, P. (Eds.). (1996). Questions of cultural identity. London: Sage. ISBN: 0803978839

Hall, S. (1990). Cultural identity and diaspora. In J. Rutherford (Ed.), Identity: Community, culture, difference. London: Lawrence \& Wishart.

Hall, E. T., \& Hall, M. R. (1990). Understanding cultural differences. Yarmouth, ME: Intercultural Press.

Hofstede, G. (2001). Culture's Consequences: comparing values, behaviors, institutions, and organizations across nations $\left(2^{\text {nd }}\right.$ ed). Thousand, Oaks, CA. SAGE publications. ISBN: 978-0-8039-7323-7

Hofstede, G., \& Hofstede, G.T. (2005). Cultures and organizations: software of the mind ( $2^{\text {nd }}$ ed). New York:McGraw-Hill. ISBN: 978-0-07-143959-6

Huntington, S. P. (1993). The clash of civilizations and the remaking of the world order. New York, NY: Free Press.

Jenkins, R. (1996) Social Identity. London:Routledge.

Kidd, W. (2002). Culture and identity. Basingstoke: Palgrave Macmillan.

Kroeber, A. L., \& Kluckhohn, C. (1952). Culture: A critical review of concepts and definitions. New York, Vintage Books.

Kwan, S. Y., \& Williams, S. A. (1999). Dental beliefs, knowledge and behavior of Chinese people in the United Kingdom. Community Health Knowledge, 16(1), 33-39.

Kwan, S. Y., \& Holmes, M. A. (1999). An exploration of oral health beliefs and attitudes of Chinese in West Yorkshire: A qualitative investigation. Health Education Research, 14(4), 453-460.

Leung, C., Leung, S., \& Chan, R. (2007). The adaptation of mainland Chinese immigrant parents of preschool children in Hong Kong. E-Journal of Applied Psychology, 3(1), 43-54.

Lewis, R. D. (1995). When cultures collide. London: Nicholas Brealey Publications.

Lewis, R. D. (2002). The cultural imperative: cultural trends in the 21st century. Yarmouth, ME: Intercultural Press. ISBN-13:9781877864988

Lindlof, T. R., \& Taylor, B. C. (2002). Qualitative communication research methods. Thousand Oaks, CA: Sage Publications.

Lo, M. C. I. L. \& Vivian K. N. (1990). Cultural Identity and code-switching among immigrant Chinese students, parents and teachers. UK: Chartered Institute of Linguists.

Manning, A., \& Roy, S. (2006). Culture clash or culture club? The identity and attitudes of immigrants in Britain. UK: Centre for Economic Performance.

Modood, T. et al's (1997). Ethnic Minorities in Britain: Diversity and Disadvange. Series: PSI report (843). Policy Studies Institute: London. ISBN: 9780853746706.

Nicola, P. (2005). Identity, culture and democratization: The case of Egypt. New Political Science, 27(1), 69-86.

Oberg, K. (1960). Culture shock: Adjustment to new cultural environments. Practical Anthropology, 7, 177-182.

Olins, W. (2004). On brand. New York, NY: Thames \& Hudson.

Parker, D. (1995). Through different eyes: The cultural identities of young Chinese people in Britain. Aldershot, England: Avebury Press. ISBN: 1856289230

Paxman, J. (2000). The English: A portrait of a people. New York, NY: Overlook Press.

Sawrikar, P., \& Hunt, C. J. (2005). The relationships between mental health, cultural identity and cultural values in non-English speaking background (NESB) Australian adolescents. Behavior Change, 22(2), 97-113.

Tan, S. H. (2005). Challenging citizenship: Group membership and cultural identity in a global age. Aldershot, England: Avebury Press. ISBN: 0754643670

Trompanarrs, F., \& Hampden-Turner, C. (1997). Riding the waves of culture. London: Nicholas Brealey Publications.

Verma, G. K., \& Bagley, C. (Ed.). (1984). Race relations and cultural differences. New York, NY: Biddles Ltd./St. Martin’s Press. Vincent, C (Ed.). (2003). Social justice, education and identity. London: Routledge.

Werbner, P., \& Modood, T. (Eds.). (1997). Debating cultural hybridity: Multi-cultural identities and the politics of anti-racism. London: Zed Books.

Woodwark, K. (2004). Questioning identity: Gender, class, ethnicity. London: Routledge. ISBN: 0415329671

Yeo, G. (2001). Chinese culture values and cultural portability. Retrieved from http://chinesem.wordpress.com/2008/02/01/ cultural-values-cultural-portability-religion/

Zhang, X. L. (2005). Communication, language and identity: Attitudes toward preserving children's linguistic identity in the UK among parents from mainland China. Journal of Chinese Overseas, 1(1), 110-120. 


\section{Appendix}

This questionnaire aims to find out whether there are differences in cultural identity between BBC and CBC. Questions for parents (Close-up questions):

1. When did you come to the UK?

2. Occupations

3. Living standards: (British middle class standards: annual income, single adult: minimum 13,400 pounds)

A. Lower middle class B. Middle-class C. Upper middle class

4. How many times do you go back to China?

5. Education level:

A. Graduate B. Post-graduate C. Ph.D.

6. Do you often watch Chinese programs? Why or why not?
A. Almost every day
B. About once a week,
C. About once or twice a month
D. Seldom

7. How long have you been living in your present place?

8. Why did you choose to live here?

A. For work convenience

B. For child or children's schooling

C. For lower price of the house

D. Feng shui

E. Near your Chinese friends

9. Your immigration status:

A. Indefinite live British citizen C. Chinese passport

10. Did you ever live in other places out of China? If so, name them, please.

11. Do you often communicate with your neighbors or communities?

A. Yes B. Occasionally C. Seldom D. No

12. Do you encourage your child/children to communicate or play with foreign friends?

A. Yes B. Occasionally C. Seldom D. No

13. Do you like listening to Chinese music, pop songs, etc?

A. Yes B. Just so so C. Dislike

14. Do you celebrate Chinese Festivals?

A. Yes, all most all important festivals

B. Yes, some festivals

C. Seldom

D. No, never

15. Do you regularly follow events that happened in China?
A. Yes, I watch CCTV almost every day
B. Yes, I read news of China online
C. Occasionally 
D. Seldom

E. No, never

16. Which language or languages do you speak at home?

A. Mostly Chinese B. Mostly English C. More Chinese D. More English E. About half to half

17. What language do you speak with your child/children?

A. Chinese B. English C. More English D. More Chinese E. Half to half

18. Your child's school grade performance or academic achievements

A. Excellent B. Good C. Just so so D. Not very good E. Poor

19. Does your child like schooling?

A. Like it very much B. Just so so C. Dislikes

20. How does son or daughter spend his or her leisure times? (You can choose more than one item)

A. Listening to Chinese music, songs

B. Listening to English songs, music

C. Reading Chinese articles

D. Reading English articles

E. Playing with Chinese friends

F. Playing with English friends

G. Doing homework

H. Doing housework

Others:

21. How often do you mix with other Chinese families?

A. Weekly B. Monthly C. Yearly D. Seldom E. No contact at all

22. How often do you mix with UK families?

A. Weekly B. Monthly C. Yearly D. Seldom E. No contact at all

23. In raising your child /children, what way would you prefer?

A. Chinese B. British C. Both

\section{Open-Ended Questions:}

1. Do you think that Chinese culture is different from British culture? In what way?

2. Which culture do you prefer? Chinese or English? Why?

3. Are you proud of being a Chinese in origin? Why or why not?

4. How do you think of teenagers dating in Britain?

5 . Who do you think you are? Chinese or British or both? Why?

6. Who do you want your children to be, British or Chinese?

7. Have you ever been treated unfairly or biased because you are a Chinese? If so, have you complained to the relevant authorities? Why or why not?

8. British reports about China are mainly negative, how do you feel about this?

9. What measures are you taken when your child refuse to follow your rules?

This questionnaire aims to find out about "Who do you think you are": a Chinese, a British, more Chinese, more British, or both.

Questions for CBC and BBC (Close-up questions):

1. Where were you born? 
A. China B. Britain C. Other country

2. If born in China, at what age did you come to the UK?

3. Schools you attend:

Primary

A. Public (or private) B. Grammar C. Comprehensive D. Religious GCSE

A. Public (or private) B. Grammar C. Comprehensive D. Religious A-level

A. Public (or private) B. Grammar C. Comprehensive D. Religious

4. Are or were there many Chinese students in your school?

A. More than 10 B. More than five C. Less than 5 D. Only me

5 . How often do you go back to China?

A. Once a year B. Twice a year or more C. Every other year D. Every two or three years E. Every five years F. Seldom G. Never

6. What are the things you did not like when you went back to China?

7. Education level:

A. Elementary B. Secondary C. Graduate D. post-graduate

8. Do you like your school or schools?

A. Yes, very much B. Just so so C. No, I do not like

9. How do you spend your leisure times? (You can choose more than one item)
A. Doing homework
B. Doing housework
C. Reading in English
D. Reading in Chinese
E. Playing with Chinese children
F. Playing with foreign children
G. Playing electronic games

Others:

10. Your favorite writer or writers (Chinese and British):

11. Your favorite cartoon characters (Chinese and British):

12. Your favorite pop stars, sport stars, film stars (Chinese and British):

13. Do your parents discourage you from playing with foreign friends?

A. Yes B. Sometimes C. Occasionally D. Seldom E. No, never

14. Do you often watch Chinese programs? Why or why not?

A. Yes, I like Chinese films

B. Yes, I learn Chinese

C. No, I do not have time.

D. No, I cannot understand Chinese.

E. No, I do not like Chinese programs.

15. Do you like listening to Chinese music, pop songs, etc?

A. Yes, very much B. Just so so C. Not very much C. No 
16. Do you enjoy celebrating Chinese Festivals?

A. Yes, very much B. Just so so C. Not very much C. No

17. Are your parents stricter with you on your studies compared with parents of your classmates?

A. Yes B. Not very C. No

18. Are you happy when your parents ask you to do more on your studies?

A. Yes, I have to work harder so that I can find a better job in the future.

B. No, but I have to because I am a Chinese. I can win their respect by studying better than my English peers.

C. No, I want to be treated the same as my classmates.

19. Do you regularly follow events that happen in China?

A. Often B. Sometimes C. Occasionally D. Seldom E. Never

20. Will you look after and support your parents when needed?

A. Yes B. No C. Not sure D. It depends

21. Do you like to save money for the future?

A. Yes B. No C. Not sure D. It depends

22. Do you like to pay in cash or credit cards?

A. Cash B. Credit cards

\section{Open-Ended Questions:}

1. Are you proud of being born a Chinese? Why or why not?

A. Yes, because we are more intelligent than other students.

B. Yes, because if you are not, others will look down upon you.

C. No, because my classmates do not like Chinese people.

D. No, because I do not want to be different from others.

E. others:

2. How do you think of teenagers dating in Britain?

A. I do not think it is good

B. My mother says it is not good, so I do not do it

C. I want to have a girl friend or boy friend, but it is difficult because they do not want to be my friend, for I am a Chinese.

D. I think it is okay. It is something natural.

E. others:

3. Do you like going to the pubs?

A. Yes, I like it.

B. I do not want to go, but my friends want me to go.

C. No, I hate it.

D. others:

4. Are your school rules the same with your family rules? If not, which one do you follow? How do you balance between the two?

5. What are the differences between you and your English classmates?

6. Do you try to imitate your classmates in order to win their acceptance? If yes, how? (Tick the things you do or add more)

A. No

B. Yes. By imitating their accent, following their dressing code, listening to same music, doing same sports, eating same food, going to pubs with them 
C. others:

7. Who do you think you are? Why? (Please give reasons)

A. Chinese

B. British

C. More Chinese

D. More British

E. Half and half

8. Do you often play with your classmates at school and after school?

A. Yes, I have many friends in my class and at school and we often play together..

B. Yes, I have to, otherwise I feel isolated.

C. No, I seldom play with my classmates because I live far from them.

D. No, they don't want to play with me because I am Chinese.

E. others:

9. Do your schoolmates like to communicate and play with you? Why or why not?

10. Which language or languages do you use at home? Why? (You can choose more than one item)
A. English, because I have to practice it
B. English, because I can't speak Chinese well.
C. Chinese, because I am a Chinese.
D. Chinese, because it is difficult to communicate in English with my parents
E. Chinese, because my parents ask me to do so.
F. Chinese, because I want to practice it.

11. Have you ever been treated unfairly or bullied because you are a Chinese? If so, how did you deal with it?

12. What is your reaction when you have different opinions with your father or mother?
A. Respect and follow
B. Respect but not follow
C. Argue with them
D. Refuse to listen
E. Others:

13. What are the aspects you don't like regarding Chinese culture? (you can choose more than one item)
A. Respect the elders
B. Giving money to support one's relatives
C. Connections (Guan Xi)
D. Thrifty
E. Modesty
F. Snobbery
G. Traditional clothing (Qipao, Tang Zhang)
H. Chinese food

Others:

14. What attitude or attitudes do your classmates hold about the Chinese?

A. Respect B. Dislike C. Biased D. Hostile E. Friendly

15. British reports about China are mainly negative, how do you feel about this? 
A. Indifferent B. Angry C. Unfair D. None of my business, because I am not a Chinese now.

16. Which culture do you prefer? Chinese or British? Why?

17. Do you think it is good to have a mixed identity? Why or why not? 